Interested non-members as weIl as members of MESA are cordially invited by the Program Chairman to submit their applications, together with preferences for country roles, to Ms. Kathleen Wilson, Center for Near Eastern \& North African Studies, 144 Lane Hall, The University of Michigan, Ann Arbor, Michigan 48109, no later than June 15. Applications should include a curriculum vitae together with a 250-word statement of purpose for participating in the project. Our purposes in launching this project are threefold: (1) to perfect and disseminate a futuristic teaching tool, (2) to ensure a continuing interaction on issues of substance between annual conferences of MESA among major scholars in the field, and (3) to derive insights about and experiment with possible processes of settlement of the Arab-Israeli conflict.

The countries to be represented will include the United States, the Soviet Union, Egypt, Israel, Saudi Arabia, Syria, Jordan, Lebanon, possibly Iraq and/or other Arab states, together with delegations of Palestinians and Europeans. Applicants should try to specify the role they wish to play, e.g., Finance Minister of Egypt, not simply Egypt, and they should present at least five alternative choices. Each team will consist of 5 to 8 players, and they will be concentrated so far as possible on individual campuses. Faculty members who wish to manage country teams consisting mainly of colleagues (including graduate students) and who are capable of writing country reports for the volume we plan to publish will be especially favored. Please note that applicants will not be expected in real life to be nationals of the respective countries they may be representing. Most of the players will be North Americans, but candidates will be selected in light of their political as well as academic experiences, so as to ensure that the roles be played as realistically and imaginately as possible.

Candidates accepted by the Program Committee will be considered to be full participants in a Workshop, hence eligible for travel grants from their universities to the 1978 and 1979 Annual Meetings of MESA. Contingent upon funding, the Program Chairman may be able to provide some travel grants. He is currently seeking funding from foundations and would appreciate any suggestions for possible sources.

\title{
NEWS OF THE MEMBERS
}

An exhibition of photographs by Nikki Keddie was shown at the Maison du Maroc in Paris this past winter. Scholars, Saints and Sufis, edited by Professor Keddie, will be issued in a paperback edition by the University of California Press this spring. Harvard University Press will publish Women in the Muslim World, which she co-edited with Lois Beck.

Professor Joseph Szyliowicz of the Graduate School of International Studies at the University of Denver has received a grant from the Duke Rand Graduate Institute Public Policy Curricular Materials Development Program to carry out a study of policy making in the case of the Aswan Dam. The case, which will involve 
an analysis of decision-making theories, will focus on the role of technological variables in the decision-making process of the major actors involved. It is anticipated that the resulting work will be used in courses dealing with policy analysis and Middle East studies. Professor Szyliowicz would welcome hearing from anyone who has done research involving the Dam.

\section{NEW MEMBERS}

The following persons are either new members of MESA or have had their membership category revised. Student members are urged to contact the MESA Secretariat upon receiving their $\mathrm{Ph}$. D. so that their membership category can be updated. Any member may have his or her membership category revised by filling out a new application form available from the MESA Secretariat.

\section{FELLOWS}

Michael I. Bates, History, American Numismatic Society, New York Tawfik E. Farah, Political Science, Kuwait University Adel Sulaiman Gamal, Arabic, American University in Cairo George J. Jennings, Anthropology, Geneva College, Beaver Falls, PA

\section{REGULARS}

Charlotte F. Albright, Near East Studies Program, Univ. of Washington Margot Badran, History Malcolm Graeme Bannerman, Political Analyst, U.S. State Department Allan Christelow, History, Bayero University, Kano, Nigeria Norman Cigar, History, University of Wisconsin at Madison Michael Collins Dunn, History, American Research Center in Cairo Haifa Fakhouri, Sociology, Detroit Asghar Fathi, Sociology, University of Calgary Judith $K$. Hecker, Arabic, Tel Aviv University Guity Nashat, History, University of Illinois Jacques Roumani, World Bank Malcolm Bruce Russe11, History, Andrews University, Maryland Martin W. Sampson, III, Political Science, University of Minnesota Philip Ernest Schoenberg, History

Boaz Shoshan, History, Ben Gurion University, Beersheva, Israel Steven I. Spiegel, Political Science, UCLA Antony Thrall Sullivan, History, Earhart Foundation, Ann Arbor, MI

\section{ASSOCIATES}

Johanna E.L. Barret, Anthropology, AMIDEAST, Washington George T. Debakey, Economics, Rockwell International, Virginia Mansoureh Niamir, Archaeology, Tehran, Iran Rene Olivieri, Economics, Praeger Special Studies, New York Frederick A. Praeger, Westview Press, Boulder, Colorado

\section{STUDENTS}

David J. Anthony, East Carolina University Anthony Chiacchio, History, Richmond College, Staten Island, NY 
Janice C. Cram, Literature, Portland State University

Susan $\mathrm{K}$. Croutwater, History, Ohio State University

Bruce Dempster, Archaeology

Josephine C. Diagonale, Political Science, Farleigh Dickinson

Behrooz Hadavi, Political Science, Johns Hopkins University

Mary Therese Hassouna, Political Science, University of Denver

Mohamed Ali Hussein

Robert George Jezarian, Philosophy, Baruch College, New York

Gerard J. Libaridian, History

Marilyn J. Lutz, Anthropology, University of Pennsylvania

Carolee Peycheff, Literature, UCLA

Liane Rosenblatt, Anthropology, University of Rochester

Michael Saracoglu, Political Science, UCLA

Kar1 R. Schaefer, Literature, New York University

Daniel Schroeter, University of Manchester, England

Brian Donald Smith, Education, Brunel University, England

\section{FUTURE CONFERENCES}

MISSOURI VALLEY HISTORY CONFERENCE :

The Twenty-second Annual Missouri Valley History Conference will be held in Omaha, Nebraska on March 8-10, 1979. Papers and sessions include the traditional topic and area studies as well as quantification, psychohistory, teaching methodology, research tools and techniques, and interdisciplinary studies. Paper/session proposals, graduate paper/session proposals, moderator/chair nominations and those for commentator should be submitted no later than 1 November 1978 to:

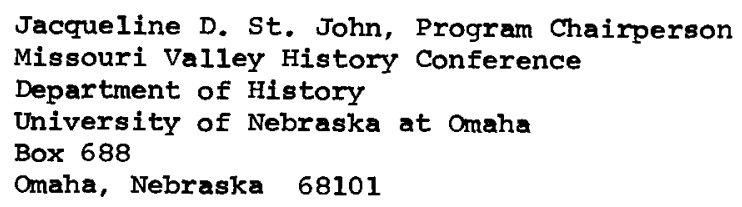

NEW DIRECTIONS FOR GLOBAL EDUCATION:

A four-day cruise along the Atlantic coast, sailing from and docking in Baltimore is one feature of this conference. Its objective is the exploration of current world conditions which call for new responses from the educational community. There will be a special focus on the findings of the U.S. Commissioner of Education's Task Force on Global Education. The ship is the S.S. Universe, registered in Liberia; operated on a non-profit basis, it is designed for educational use. The dates of the conference are June $16-19$, the conference fee (inclusive) is $\$ 225.00$. For further information write:

Conference Director, Shipboard Conference

AACTE, One Dupont Circle

Washington, D.C. 20036

(AACTE--American Association of Colleges for Teacher Education) 